Article

\title{
Memory in Sacred Places: The Revitalization Process of the Muisca Community
}

\author{
Paola Andrea Sánchez-Castañeda \\ Department of Global and Sociocultural Studies, Florida International University, Miami, FL 33199, USA; \\ E-Mail: psanc064@fiu.edu
}

Submitted: 6 April 2020 | Accepted: 15 June 2020 | Published: 31 August 2020

\begin{abstract}
The Muisca community of Suba, located in Bogota, Colombia, is a place-based community whose epistemology is rooted in what is now an urban environment. After enduring over five centuries of segregation, marginalization, displacement, and near cultural obliteration, the Muisca community has thrived to the present day and is currently undertaking the task of re-indigenization through the revitalization of their traditional knowledge and the process of ethnogenesis. The effects of urbanization on the Muisca have not only changed the physical spaces which they inhabit, but it has also disrupted the relational patterns between the community and their sacred places. This severing of the community from their sacred places has had the effect of further invisibilizing the Muisca's ethnic identity in the national social imaginary. As a form of resistance to their marginality, the Muisca are engaging in symbolic practices, in both public and private spaces, as a means of cultivating ideological resistance, memory revitalization, and generating new meanings of their collective identity. This article, based on an ethnographic case study, seeks to examine how the Muisca community is symbolically re-appropriating their sacred places in this urban context to mend the social fabric of the Muisca community. As such, this revitalization project represents an attempt to reconstruct a forgotten indigenous identity by rewriting the historical memory of a community that disappeared from the national discourse.
\end{abstract}

\section{Keywords}

Colombia; Indigenous communities; memory; resistance; sacred places; urban indigeneity

\section{Issue}

This article is part of the issue "Cities of Inclusion-Spaces of Justice" edited by Anja Nygren (University of Helsinki, Finland) and Florencia Quesada (University of Helsinki, Finland).

(C) 2020 by the author; licensee Cogitatio (Lisbon, Portugal). This article is licensed under a Creative Commons Attribution 4.0 International License (CC BY).

\section{Introduction}

Mi territorio, 'jicha,' es la conjugación de varias cosas. La superficie [y] el espíritu que habita allí. Es la parte física pero también las relaciones espirituales que guarda la tierra. (My territory, 'jicha,' is the junction of several things. The surface [and] the spirit that lives there. It is the physical part but also the spiritual relationships that the Earth keeps; Interview with a member of the Muisca community of Suba, 2017)

Considering the rapid expansion of cities around the globe, the experiences of indigenous communities traditionally inhabiting those new urbanized spaces appear as a necessary focus for research in urban stud- ies. It appears that the imaginaries of rural indigeneity are what determine the spatiality of the urban indigenous communities (Bocarejo, 2011), therefore making urban indigeneity a contradiction. Although significant attention has been given to the subject of recognition of land property in rural spaces, less attention has been directed towards the experiences of traditional inhabitants of indigenous communities within cities. While contemporary scholarship has explored urban settler colonial spaces, particularly within the Australian and Canadian experience (Povinelli, 2002), fewer studies have been done in places such as Latin America, where the colonial legacy remains present in those spaces. As Jane Jacobs affirms, in cities there remains "a very specific local politics deeply marked by the historical legacy of the colo- 
nial dispossession of indigenous peoples" (Jacobs, 1996, p. 105). Nevertheless, this invisibility of indigeneity in urban spaces has been challenged through processes of revitalization of indigenous identity.

These processes of revitalization have increasingly taken place since political spaces began to open during the last decades of the twentieth century around the world. However, one can suggest that the political recognition of these movements is only a formal acknowledgment of cultural, social, and spiritual realities that have been backgrounded over centuries by the hegemonic structure. These global platforms, under the umbrella of the multicultural turn, amplified the reach of revitalization discourses and pushed certain national policies to acknowledge their pluri-ethnic identities (Ng'weno, 2007). For many indigenous communities, these processes of revitalization, also known as re-indigenization, have entailed the active and conscious path of reinterpreting their history through the constant battle between the historical and hegemonic discourse and their community's traditional history (Hill, 1996). In this sense, communities undergoing revitalization processes pose a direct challenge to the identity imposed onto them by the State and the academy, which have served to perpetuate essentialisms of indigenous identities (Ellison, 2018; Kuper, 2003). In contrast to those imaginaries, indigeneity in the urban environment is lived, negotiated, and constantly re-interpreted; it is negotiated within the spaces where it is present, while it also undergoes continuous change. As several scholars have argued (Alfred \& Corntassel, 2005; Maddison, 2013; Shulist, 2016; Weaver, 2001), the imposition of those essential imaginaries of indigeneity not only misrepresents the reality of the communities, but also harms their processes of identity formation insofar as "such images of indigeneity, colorful and exotic, bear little resemblance to the lives of real people. Moreover, they can serve to dictate to Indians the parameters of their own identity by defining what is "properly" Indian or indigenous" (Canessa, 2005, p. 4).

Nonetheless, as this article shows, resistance to those imposed indigenous identities, including their spatialization comes from below; it emerges from the indigenous community's efforts to keep their traditional roots in local, familiar and personal spaces by way of re-appropriating their sacred lands through rituals and performances. Therefore, demanding spiritual liberties and, above all, rights to access and ownership of their sacred lands, is the principal goal of several communities in the pursuit of decolonizing their spaces, bodies, and memories. I am particularly interested in the process of revitalization of the Muisca community in Suba, Bogotá, Colombia. Recognized as the first indigenous community located in an urban environment in Colombia during the 1990s, the Muisca community of Suba has faced centuries of marginalization, segregation, cultural obliteration, and with modernity, displacement, and invisibility. Although the Colombian legislation, through Constitutional changes in 1991, has granted access to communal lands for ethnic minorities including indigenous and black communities, this process of spatialization has been put into action differently in urban environments, leading to the lack of land for the Muisca community. The ambivalent articulations of the legal framework regarding ethnic land reveal how the historic struggles over land take place in the urban space, where local policy continues to reproduce colonial regimes of dispossession of Indigenous lands.

Based on ongoing ethnographic research since 2017, I have used participant observation, in-depth interviews, and visual methodologies to engage with the Muisca of Suba's process of identity revitalization and land claims. I have conducted participant observation in events such as general assemblies, elections (which take place every year), seasonal festivals, census, palabreos (reasoning gatherings), hikes to the sacred mountains, rituals in their orchards, and educational sessions. Likewise, during those events, and in private sessions, I have conducted over 50 semi-structured and unstructured interviews to adult members of different groups, such as the Consejo de mujeres (women council), Consejo de abuelos, mayores y sabedores (elders and wise council), Consejo de jovenes (youth council), and with the political authorities of the community to gather a diverse set of experiences. Finally, I have engaged with visual methodologies including photography and video, in addition to drawing on visual material produced by members of the community themselves during public and private gatherings, rituals, and performances. In drawing on visual methods, I demonstrate how these sources can be used as a powerful instrument of visual representation of the Muisca of Suba's identity in their own places and contexts. As echoed in the community, their existence has been invisibilized, therefore, pictures and video materialize their presence.

In this article, I want to address how the Muisca community's process of revitalization is a form of resistance which involves symbolic practices such as rituals and performances in both private and public spaces. I seek to examine how the community is symbolically re-appropriating their sacred places in the city as an attempt to make their identity visible while reconstructing the historical memory of their community's members. I divide this work into two main sections: In the first section, this article explores theoretical debates on how indigeneity is spatialized, negotiated, and contested through everyday practices, particularly in the urban environment (Escobar, 2008; Lefebvre, 1991; Zieleniec, 2018). In the second section, I address the Muisca community's process of revitalization as a process of resistance which, through private and public rituals and performances, is re-appropriating their sacred land in the face of displacement and marginalization.

\section{The City as a Space of Indigenous Alterity}

Urban space has been problematized as a highly politicized and institutionalized, but contested space. On the 
one hand, the urban environment has been shaped as a space where modernity is emplaced. Here, public spaces are organized to reproduce the relations between property, law, and planning as a means of perpetuating the needs of modern capitalism (Zieleniec, 2018, p. 10). On the other hand, the city appears as a space where possibilities of resistance to this functional logic remain present. In thinking on Lefebvre's work, the city also serves as a place of hope in which urban planning is thought of in terms of lived space, rather than a mere "functional habitat impelled by the needs of power and capital" (Zieleniec, 2018, p. 5). Understanding the urban space in these terms opens the spectrum of possibilities for social movements, among which indigenous communities are present (Blomley, 2004).

According to some theorists, both urban planning and property laws appear as mechanisms of governance insofar as they are seen as technologies of power that "shape material forms and social activities in urban space" (Wideman \& Lombardo, 2019, p. 3). Far from being neutral, the molding of urban space follows certain imaginaries, none of which concerns ethnicity and race. The scholar Brenna Bhandar (2018), for instance, has developed the concept of 'racial regimes of ownership' to argue how there is a relationship between property regimes and race as a legacy of colonial presence. Racialization of space and nature, therefore, remains a powerful force in contemporary society (Brahinsky, Sasser, \& MinkoffZern, 2014, p. 1135). In a similar way to Bhandar, other scholars have also suggested the racialized logic of land property in cities (Heynen, 2016), arguing that "exclusion was secured through a complex of everyday practices, most notably segregation and de facto discrimination in schools, workplaces, public offices, and local markets" (Pallares, 2002, p. 62). These ethnic spatial fixes (Povinelli, 2011) show how property and its concomitant legal structures are constantly being enacted within settler-colonial cities to facilitate dispossession and settlement.

Nevertheless, practices of resistance appear to subvert exclusionary logics of spatialization. Echoing the classic work of Henri Lefebvre (1991), the production of space is also possible through the everyday, collective lived experience which provides meanings of what Lefebvre refers to as representational spaces. While the modern-liberal logics of urban planning seems to be impermeable, the collective right to the city appears as an everyday process of appropriation of space that "prioritize[s] its use-value over its exchange value" (Wideman\& Lombardo, 2019, p. 7). A rich scholarship has emerged in cities across the global south, particularly from Latin America, where scholars have echoed Lefebvre's notion of space as a process. In debates over the ambiguous and politicized use of the word territorio (territory), Latin American scholars have suggested that like space, territorio appears as an endogenous concept that responds to the history, geography and multiple forces that are grounded in place in this region (López
Sandoval, Robertsdotter, \& Paredes, 2017, p. 43). This debate seems relevant, since, for some social and ethnic movements throughout the continent, the urban space is where their territorio is located. The city appears as a space of indigenous alterity, as a space for alternative epistemologies.

In contrast to the liberal construction of the urban space, indigenous epistemologies allow for an alternative perspective on the relationality that is lived within this environment (De la Cadena, 2015). Understanding the city as indigenous territory brings possibilities of "relational understandings of time and space that included human and non-human beings" (Bryan, 2012, p. 219), towards a more inclusive and just space. In the second section of this work, I am interested in how the Muisca community, like other "urban indigenous groups in Bogotá...have openly contested the strong legal spatial associations of indigenous groups and minority rights" (Bocarejo, 2011, p. 665). In contrast to the urban ethnic invisibility presented in urban planning in some Latin American countries, this process of indigenous revitalization presents how "the built environment is a crucial site for observing indigeneity-in-the-making, allowing one to historicize its contemporary importance as far more than an invention" (Hobsbawm \& Ranger, 1983). In this sense, both the community and the urban space produce, negotiate and contest their identities, in a coconstitutive process.

\section{The Right to Sacred Space: The Muisca Territorial Appropriation}

El territorio es sagrado, es vital. Un pueblo sin territorio es como un pez sin agua, es lo que nos identifica, es lo que nos hace ser una comunidad. Nos trae diferentes sensaciones, son olores, son sentires, colores, expresiones. El territorio es mi mamá, mi protección, la unión de todos los elementos. Para mí, territorio es vida, pero siempre que yo cuento la historia, hay una fractura, hablar de territorio siempre me llena de nostalgia. (The territory is sacred, it is vital. People without territory is like a fish without water. It is what identifies us, it is what makes us a community. It brings us different sensations, it is smells, it is feelings, colors, expressions. The territory is my mom, my protection, the union of all the elements. For me, the territory is life, but whenever I tell the story, there is a fracture. Talking about territory always fills me with nostalgia; Interview with a member of the Muisca community of Suba, 2017)

During the nineteenth and twentieth centuries in Latin America, social constructions of indigenous peoples throughout the continent operated as discursive mechanisms which were used to misrepresent these communities within the cultural and economic realms, and in particular, in terms of ownership of the land. Categorizing the indigenous epistemologies as backwards and against 
Western ideas of progress and development, this national discourse permeated the national imaginary and helped to maintain a hegemony of Eurocentric epistemology (Quijano, 1997, p. 117). During this timeframe, indigenous peoples were also classified in economic terms as peasants, which changed their relationship with their communal lands. In a pursuit to keep ownership over the lands they inhabited, indigenous communities had to buy or demonstrate their title deed through legal documents which, most of the time, they did not possess. The institutionalization of land rights within the economic liberal thinking was without a doubt, one of the most powerful and subtle governmental mechanisms of ethnic disintegration and displacement. Despite the end of the Spanish colonial system in Latin America, "internal colonialism [has been the] reformulation of the colonial difference within the formation of the modern nationstate after decolonization" (Mignolo, 2000, p. 197). The interiorized racial imaginary from the colonial period has remained, it has mutated, but certainly, it can be perceived not only in the legal structure but in the social imaginary itself.

During the last decades of the twentieth century, there was a significant shift in political discourse which moved towards indigenous recognition. Multiculturalism emerged as a political platform which, despite being framed within neoliberal policies, allowed for a transition to the indigenous struggle for recognition and differentiated rights. Moving from complete invisibilization"from monoracial liberalism to multicultural neoliberalism" (Sánchez-Castañeda, 2018, p. 15)-indigenous communities, such as the Muisca of Suba, envisaged in the new multicultural policies a hope for their struggle for identity and land recognition. However, as some scholars have argued, multiculturalism operates as political mechanism of governance, allowing the states to secure a minimum of control over the resurgent identities, once the racially homogenous project of a nation was no longer successful (Escobar, 2008, p. 213).

As a consequence of centuries of colonialism, some have stated that "despite the language of multiculturalism in many nations and even constitutional reform any assertion of Indian identity is likely to be resisted by at least some of the political and social elite" (Canessa, 2005 , p. 3). In this sense, the economic and political elite that opened the space for a pluri-ethnic recognition would remain the same that determines the relation between the communities and their territories. As a result, the political and economic elite which ushered in multicultural policies in Latin America continued to aggressively subjugate the environment and those minority groups whose values undermined capitalism. Following Marcuse, capitalism approaches nature "in an aggressively scientific way: It is there for the sake of domination; it is value-free matter, material. This notion of nature is a historical a priori, pertaining to a specific form of society" (Marcuse, 2018, p. 74). This form of society that in the same way that constructs an 'otherness' to the in- digenous, also others nature to impose its power (Malm, 2018). The process of constructing an 'other,' whether it be nature or an indigenous community, is essential to territorial exclusion, misrepresentation and moral distancing. It represents a process that is foundational to colonial and imperial discourses, and has worked to justify the economic agenda of the colonies through the othering of indigenous peoples and nature.

\subsection{Suba: Flower of the Sun}

In muysccubun - the native Muisca language that is in the process of revitalization-Suba means 'flower of the sun' or 'flower of quinoa.' Suba is a locality within Colombia's capital city of Bogota. The locality is situated in the northwest region of the city, and is populated by more than one million inhabitants scattered throughout, including approximately 2,500 families-which represents around 8,000 people-that are Muisca indigenous. The district of Suba stands out among the rest of the other districts in Bogota in virtue of its biodiversity and landscapes, being a space where rurality is present in the city. Given these characteristics, Suba has been the target of multiple luxury real estate construction companies that, regardless of the vast inequality lived in the district, aim to produce exchange value over the sacred lands of the Muisca community. Historically, based on the accounts Muisca members I interviewed, there is a strong sense of discontinuity of their presence in this locality due to the multiple processes of colonization and internal colonization experienced by the community. One can trace the process of land dispossession back to the encounter with the Spanish colonizers. In contrast to other communities' experiences, the Muisca people of Suba affirm that the process of catholic conversion responded to political dynamics between their cacique (indigenous political leader) and the colonizers, as this member states:

In 1537, the conquerors arrived at Suba. [Since] they arrived during the Holy Week, they were being pacifist instead of coming aggressively to this territory. They [the Spaniards] had been in the Americas for some time before, so they knew a couple of things about the organization in the communities. In the case of the Muisca community of Suba, the Spaniards took advantage of the old local quarrels to take control of these territories. The 'cacique' was converted to Catholicism, being the first Catholic Muisca. Moreover, three days after his baptism, he died. That was because he betrayed his beliefs, his community, and his identity. (Interview with a member of the Muisca community of Suba, 2017)

The settlement of the Europeans in Suba was made possible through establishing relationships with the local leaders; However, this dynamic was not well received by the entire Muisca community. In less than a century, the po- 
litical arrangement between the European settlers and local leaders was no longer legitimized by the indigenous population, leading the colonizers to establish control over the territory without the support of the caciques (Langebaek, 2005). While the political authorities lost validity among the Muisca population, at the base of the social structure, the religious authorities resisted the assimilation of Spanish culture through creative adaptations of their cosmology to the reality of the colonial times. It was through the continuation of these practices, even in private spaces, that the assimilation of the Muisca culture was not a complete process. Although the exploitation of indigenous peoples and their lands has taken place since the Spanish colony in Suba, territorial institutions such as the resguardos-territorial communal unit administered by the indigenous peoples and legitimized by colonial titles-allowed the communities to maintain to a certain degree their traditional practices in-place. However, from the sixteenth to the twentieth centuries, under the laws of the Republic and its racial homogenization agenda, the dissolution of the resguardos reconfigured the Muisca's access to their lands. The results of these measures for the Muisca were a loss of autonomy and an integration of their community within the new nation into broad categories such as peasants and semiurban workers (López, 2005, p. 333).

Notwithstanding the invisibilization of their identity, the Muisca community maintained a significant amount of traditional practices from within the marginality of their houses and pieces of land which, until the 1950s, constituted a great percentage of the region of the town of Suba. However, with the abrupt flows of migrants from many places in Colombia, urbanization became another threat for the community which had to start selling their lands facing the reality of possible expropriation. For the Muiscas, as for other indigenous communities throughout the Americas, pueblos (towns) "represent an intermediary space-not necessarily a place of transition between rural and urban life but a permanent in-between. Pueblos are the symbolic and ceremonial center of the rural highlands" (Pallares, 2002, p. 61). However, in the name of development, this town became a locality of the capital of Colombia in 1954 by a presidential decree. Suba went through a sudden urbanization of its rural areas wherein the Muiscas had their lands, not only displacing them but also disintegrating the families. As part of the capitalist agenda, ethnic epistemologies do not have a value in the market, therefore, they must be removed from those profitable lands, following the idea of progress. As Escobar affirms, "displacement is an integral element of Eurocentric modernity and development. Modernity and development are spatial-cultural projects that require the continuous conquest of territories and peoples and their ecological and cultural transformation along the lines of a logocentric order" (Escobar, 2008, p. 65). With the "desacralization of [their] place" (Routledge, 2017, p. 82), the Muiscas started a process of conscious resistance as a commu- nity with a place-based epistemology. The community has since grounded their struggles in their territory, a space that has been irrupted, but is now being redefined through both the recovery and generation of traditional knowledge, memories, and relations.

During the 1970s, a group of Muisca families began a process of resignification of their own identity which contested the historical categorizations and representations of the Muisca produced by those in rule (Cabildo Indígena Muisca de Suba, 1999). The social insurgencies throughout Latin America for peasant and ethnic rights served as models for many social movements to explore mechanisms of resistance and resurgence; indeed, in response to the socio-cultural pressures, a series of constitutional reforms took place across the continent, leading Colombia to establish a new constitution in 1991. The Constitution of 1991 classified Colombia as a pluri-ethnic nation which recognized the diversity of ethnic and cultural groups. From a critical vantage point (Sánchez-Castañeda, 2018, p. 19), however, the constitution and its regimes of recognition became a means of pacifying the social movements emerging across the continent and worked to manage cultural diversity while legislating the minority populations. As such, the multicultural political agenda in Colombia can be seen as a form of "colonial governmentality" (Coulthard, 2014, p. 15).

The Muisca's revitalization of their identity began with an inner desire to destabilize those national imaginaries that kept them in the pre-Columbian past and categorized them as peasants, thereby attempting to erase their history. Through the revitalization process, the Muiscas have regenerated an epistemology which has been hidden in their past, but has nevertheless remained present in their practices. Today, the Muisca's revitalization practices can be understood as "a process...[a] new indigenism [that] seeks to undo hegemonic signifiers, affect their usual semantic chemistry to produce new valences, and thus reconfigure indigeneity itself opening it up to the acknowledgment to historical contemporaneity and radical social justice" (De la Cadena \& Starn, 2007, p. 11).

\subsection{Embodied Memory and Resistance}

Public and private spaces have become the scene of collective activities, such as performances, where the Muisca community challenges the national imaginary by way of sacralizing those spaces that have been transgressed by capitalist perspectives of profit. In contrast to those economic perspectives based in capitalist logic, indigenous senses of place tend to situate culture within place, and therefore root their epistemology where "no degree of globalization can ever reduce place to the logic of capital, technology, or transnational media" (Escobar, 2008 , p. 317). The Muisca's symbolic appropriation of their taken lands through performances has been a powerful tool of identity contestation to those who do not legitimize them as 'real indigenous.' These perfor- 
mances can be viewed as displays of how the Muisca tradition remains alive in the urbanized town, confirming what Routledge argues in stating that "performance and the performance of emotions have become increasingly important in the practice of politics" (Routledge, 2017 , p. 114). Through appropriating public spaces, the Muiscas exercise their right to appear and perform in the public space, converting their bodies into political sites that demand "for a more livable set of economic, social, and political conditions no longer afflicted by induced forms of precarity" (Butler, 2015, p. 260). In another way, ritual also becomes a powerful embodied tool to rebuild the Muisca's communal identity along with their sense of place. Insofar as their cosmology is being re-constructed and revived through the appropriation of their ancestral spaces, their bodies become living extensions of their sacred territory and their memory:

A major component of such remembering has to do with the how bodies remember certain places to have been and how orient and reorient themselves in regard to these same (and like) places. Similarly, cognitive maps, regarded as internalized representations of places, play a powerful role in orientation, often acting in conjunction with body memories. In both instances, places ingress into bodies in enduring and significant ways. (Casey, 2009, p. 103)

While the local government of Bogota has officially recognized the presence of Indigenous communities throughout the city in Decree 543 written in 2011 (Alcaldía Mayor de Bogotá, 2011), there has yet to be a restitu- tion of lands to the Muisca community of Suba to this day. Therefore, through these rituals, the Muisca community aims to reestablish a sense of control over their sacred lands by consciously creating communal spaces of embodied connection to their territories. For this purpose, within their process of revitalization, the Muiscas have also engaged with, and re-signified, their mythology (Carillo, 1997). By invoking and re-signifying their mythology and cosmology while remaining present in these public yet sacred places, the Muiscas have created an ongoing ritual practice which regenerates and strengthens their communal memory. As Jenkins affirms, these rituals in particular places are innate to the indigenous ways of being in the world, "for many Indigenous peoples their way of life-including their stories, cosmologies, identities, and much else that we might put under the (perhaps alien) heading of 'religion'-depends on the intimate connection to specific creatures and particular places" (Jenkins, 2017, p. 242). For instance, one of the series of rituals which I attended was called, paisajes sonoros (soundscapes). This symbolic practice of place appropriation was a way to reclaim their ownership and relationships with places that are no longer maintained as sacred indigenous places. Through walking, listening, and speaking to the places in their native language, the Muiscas were remembering in place what these locations meant for the social fabric of the community. Open to Muiscas and non-indigenous visitors, we walked for four Sundays throughout different places that are recognized as sacred by the community: the Tibabuyes wetland, the Indio Park, the Nevados Park (Figure 1), and two mountains located in the eastern area of the locality. Some political au-

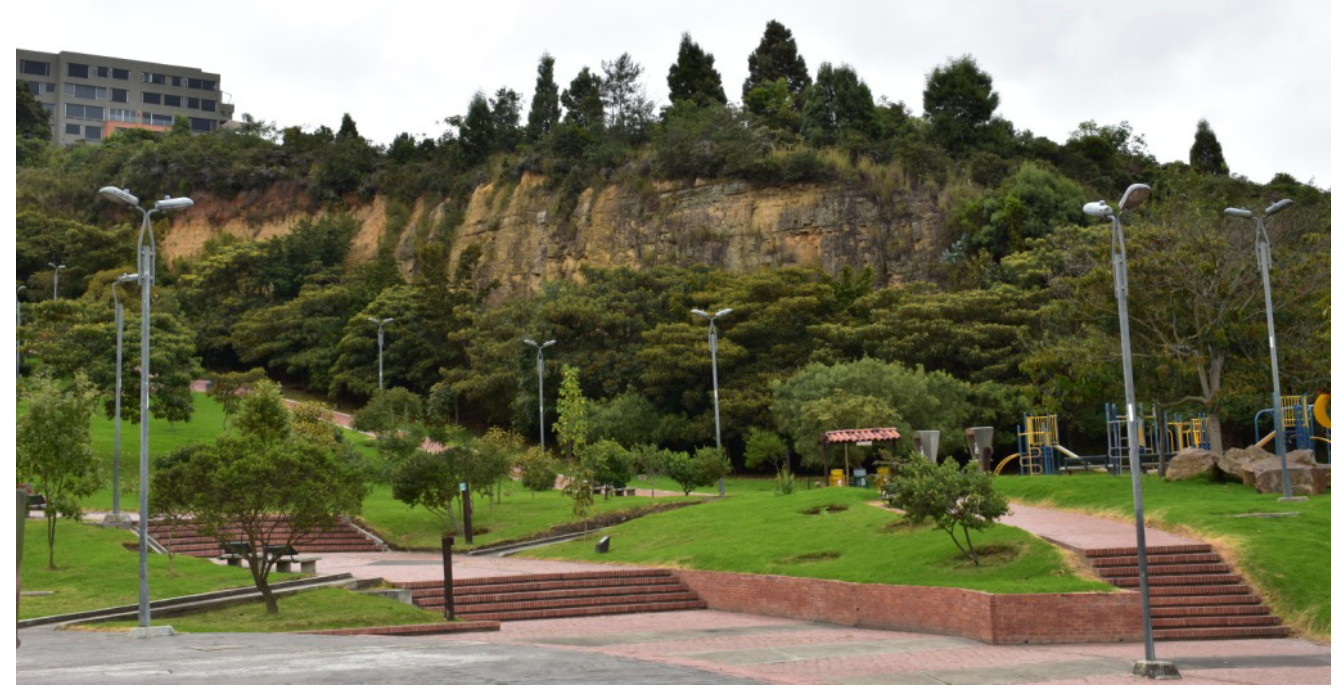

Figure 1. Los Nevados Park, June 2017. This sacred place for the Muisca community is under the administration of the government of the district. While it is a public park, there is a group of Muisca families-raizales (traditional inhabitants) who remain living in the park. 
thorities and youth members of the community encouraged elders of the community to share their memories in place along with fragments of their sacred myths to be recorded as part of the digital archive of the community. Although some elders remain residents of areas around their sacred sites, most of the Muisca families have been displaced to other parts of Suba as a consequence of the expansion of the urbanization. In some cases, these activities of remembering carry an incredible sense of grief for the elders who have signified these places as sacred. The elders understand these places as parts of their family, and even extensions of their bodies. For the Muisca community, however, these rituals of remembrance are recognized as practices of healing their communal memory.

In the same manner, the Muisca community has engaged in seasonal celebrations in public spaces such as the main plaza of Suba. Town plazas have been essential public spaces where religious, political, and social authorities encounter one another, and also where peasants take their products on a weekly basis. The town plaza of Suba, in particular, was the center of the indigenous town during the arrival of the Spanish colonizers (Zambrano, 2003). Therefore, for their most important celebrations, such as solstices and equinoxes, and political events such as census and annual elections, the Muisca of Suba continue using this plaza as a public space that has to be reclaimed as Muisca territory. In one of these celebrations, what they called the Quinoa and Corn Festival, the Muisca held a day-long celebration in accordance with the solstice celebration (Figure 2). After a communal ritual of harmonization made by one active elder of the community, which consists of paying rever- ence to sacred places in each of the cardinal directions and a cleanse with traditional herbs, the Muisca people started performing traditional dances to the sound of Andean music played by some members of the community. Likewise, many Muiscas were offering their products in different tents installed throughout the plaza; products such as pottery and handmade woven bags, or mochilas, as well as traditional food products such as arepas (cornmeal cakes), and chicha, a traditional fermented beverage which was prohibited for decades, that now has become a symbol of Muisca resurgence.

Whereas public appropriations of space have served to challenge outsiders' imaginaries, private spaces have kept their essence as places where their indigenous identity has been alive for centuries. Private spaces have been where traditional practices such as cooking, healing, and reasoning through their linguistic hybridizations have served as micro-practices of decolonization that have survived the multiple attempts to erase them. As Corntassel suggests, "often daily actions are overlooked during discussions of community resurgence and selfdetermination movements" (Corntassel, 2018, p. 17), leaving aside the valuable meaning of those hidden practices in the reproduction of culture. What urban indigeneity has meant to the Muiscas is a constant redesigning of mechanisms of cultural survival, but particularly of economic renegotiations. For instance, through the communal gardens initiative, members of the community with bigger lots-remains of what used to be their ancestral lands-have set up orchards which produce and guarantee a certain level of food sovereignty, in addition to helping the community reestablish their connection

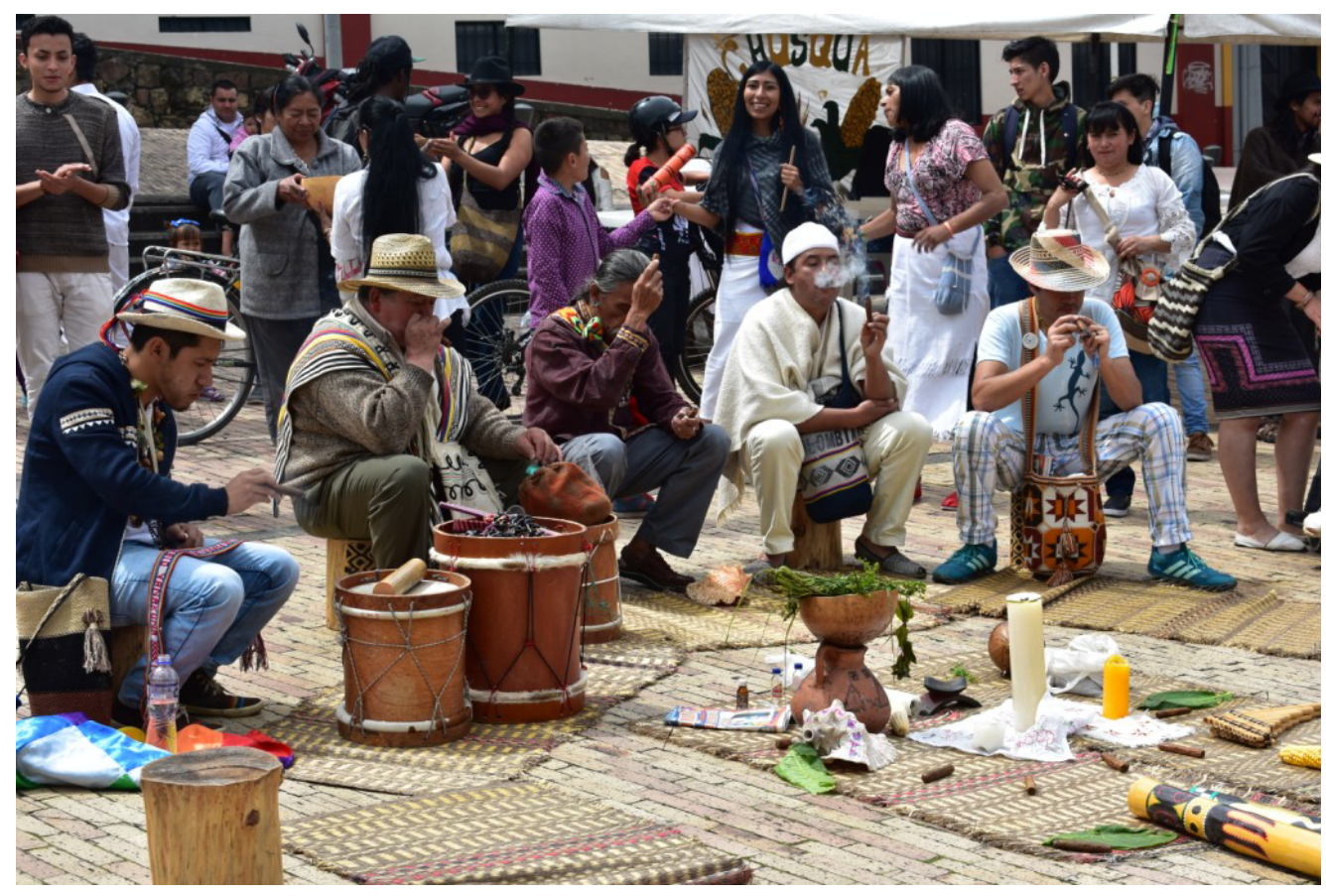

Figure 2. Quinoa and Corn Festival, June 2017. Members of the community using tobacco and coca leaves as a means to appropriate the main plaza of Suba in one of their main annual celebrations. On the back, women are sharing chicha, a symbolic fermented beverage. 
with the land and thereby reconstruct their social fabric. After the dissolution of the resguardos-indigenous territorial units under colonial rule-some indigenous families were able to acquire pieces of land in what used to be the town of Suba and keep their ownership until present times. However, for other families, there was not a possibility of buying their ancestral lands or keeping them after the abrupt process of urbanization (Zambrano, 2003).

Nevertheless, some families have opened their gardens to the community, recreating a sense of place, while renewing their connection with their land while "regenerating urban space" (Manzini, 2015, p. 190). For instance, in one of the gardens opened to the community, youth Muisca members in charge of the educational activities have promoted the revitalization of their native language in place. For several Sundays in July 2018, we would arrive at one of the community's gardens located on the top of a mountain in Suba early in the morning to set up lunch for the families that had facilitated the gathering. After a harmonization of the space, led by the tanyquy-spiritual leader-we started cleaning the garden and cooking; another woman and I were in charge of the fire, for the Muisca people women are the only one's allowed to light the fire. At the same time, one of the educational leaders started with the language lesson using memories at these places as a means to teach muysccubun (the native Muisca language).

Another element which was present in these educational sessions, as well as in other gatherings, has been the use of tobacco and coca leaves as substances of resistance. While these plants have historically been demonized and stigmatized in Colombia, the consumption of these substances is viewed as an important practice of communal healing and connection with the territory for the Muiscas. In contrast to the perspective of non-indigenous citizens in the city who have attached negative meanings to these substances and to practices associated with them, the Muisca people argue that in addition to helping make meaning of the territory of Suba, "the consumption of these substances allows the ceremonial concentration, the strengthening of loyalty within the community and even, collective decisionmaking" (interview with a member of the Muisca community of Suba, 2018).

Instead of reducing the land to mere space to be exploited as a commodity, placemaking has become an activity of resistance that is "strengthening people's capacity to withstand the traumas of capitalist modernity (from poverty to war) in place, building on people's struggles for the defense of place and culture, and fostering people's autonomy over their territories" (Escobar, 2008 , p. 64). Not only have the Muiscas designed multivalent mechanisms of resistance which constitute actions in the margins of society which challenge the system of production and exchange within a capitalist system, but their practices also attest to the multiplicity of ontologies through the embodiment of alternative ways of being in the world. The recovery of their land goes hand in hand with the recovery of their ancestral knowledge, their history, their identity, and their reciprocal relationship with the land. It is the reconstruction of a place, where the territory as a living entity, reclaims its memory (Ulloa, 2012).

\section{Conclusions}

The subjugation of indigenous identities has been historically connected with the transgression and degradation of their territories. Displacement, urbanization, and other desacralization methods have impacted how the natives have made sense of place, and therefore how they make sense of their existence. This marginalization of place and its relationships with a multiplicity of actors "has had profound consequences for our understanding of culture, nature, and economy" (Escobar, 2008, p. 30). However, even in the subaltern spaces where some communities have remained for centuries, they have faced their reality through developing unique mechanisms of cultural survival.

Cases such as the Muiscas of Suba represent other ways of being in an urban environment that respects the environment while reenvisioning their existence in relation to it. Certainly, given the current global environmental crisis underway, "we should foster the coexistence of solutions based on different logics and different rationales" (Manzini, 2015, p. 192). In addition to fostering this coexistence, however, challenges to the "coloniality of being" (Maldonado-Torres, 2007, p. 242) are being undertaken by the Muisca community, whose resilient nature attests to the human potential to recreate and transform crisis into hope. The revitalization of the Muisca community's identity signifies a challenge the globalized discourses of progress and development in an urbanized environment that has left limited space for ethnic peoples. Their engagement with ritual and performative practices not only poses a challenge those political efforts aimed at reintegrating the Muisca identity within the national discourse, but these practices are also fundamental activities and reconciliations with the Muisca memory which strengthens the fabric of their community.

Similarly, like other local marginalized communities that have been subjugated by colonial domination, the Muisca continue to engage in everyday practices "of being, knowing and doing" while actively constructing "their socio-natural worlds" (Escobar, 2008, p. 31). Through the analysis presented here, the Muisca can be understood as an indigenous community that is rooted in what they consider to be their sacred land which has been taken from them and violated in front of their eyes. After centuries of marginalization, including the multiple strategies which have been aimed at the erasure of their ethnic identity, the Muiscas continue to thrive and remain present. In carrying on the traditional practices of Andean life, the Muisca epistemology has survived as a testament to the resilient nature of this community. 
As Restrepo (2005) affirms, the Muisca people continue enduring their present as the product of their unresolved past; a present that manifests the multiple ambiguities, disputes, and mechanism of resistance that had to take place against centuries of Spanish colonization, and later on, internal colonization during the Republic. Although obscured, the Muisca memory has come to us, and it needs to be confronted and reinterpreted.

For the Muiscas of Suba, the regimes of authenticity (Alfred \& Corntassel, 2005; Maddison, 2013; Shulist, 2016) imposed by the Colombian state have signified constant challenges against the delegitimization of the resurgence of their urban indigenous identities, situating them within discourses of false ethnic identity. This has resulted in the loss of their legal recognition once before, due to the lack of 'indigenous diacritic markers' listed in a governmental authenticity exam. In response to this, the community engaged with practices that could represent those imaginaries, in order to be recognized once again by the State. In addition to the romantic depiction of the Muiscas, there also remain essentialized representations of indigenous peoples which have further commodified their identities (Canessa, 2012; Vega, 2017).

Despite their current process of reindigenization, the national imaginary of the Muiscas continues to romanticize them as the legendary Andean civilization that was extinguished during the colonial period. Although this strategy had originally served as a means to not take responsibility for the structural violence exerted on this community in the past, it continues to marginalize the Muisca's revitalization today. In this regard, while the Colombian state has recognized the Muisca community of Suba, as well as other Muisca communities such as the one located in Bosa-a locality in the south of the city of Bogota-only one Muisca community which is not located in the city has been granted with territorial rights, the Muisca community of the town of Sesquile. While this article offers a window into the experience of the Muisca people of Suba, it also reveals how territorial struggles for indigenous communities play out in different environments. Given that the Muisca of Sesquile reside in a rural environment, and are therefore the only Muisca community to have been granted territorial rights, they fit the State's spatialization of indigenous identity while the Muisca of Suba and others remain landless. Although through Decree 543 of 2011, the district of Bogota clearly contemplates the foundation for a public policy for indigenous people in the city, little has been materialized in the everyday lives of the Muisca peoples in respect to their territorial claims. And despite the fact that Article 7 of the Decree contains a section on territorial policies or camino territorio (territorial path; Alcaldía Mayor de Bogotá, 2011), which promulgates identifying, characterizing, and re-signifying the Muisca territory in the city in accordance with the community's understandings of memory and ancestral practices, there has yet to be any specific actions taken by the city to fulfill these declarations. However, despite these pressures, the tra- ditional knowledge of communities such as the Muisca of Suba continues to survive and exhibits the potential for new understandings of the relationship between indigenous communities and urban space. Everyday practices, and public and private performances of territorial appropriation, not only stand as examples of how indigenous identity is negotiated within urban space but also shows how indigenous groups embody their relationship with their sacred lands, thereby carrying on the legacy that they have had in this place for centuries.

\section{Acknowledgments}

I would like to thank the Muisca community of Suba, in Bogotá, Colombia, for sharing their ancestral knowledge and everyday experiences of resistance with me. I am also extremely thankful to Anja Nygren and Florencia Quesada for organizing this thematic issue and providing valuable commentary on the first draft of article, as well as three very helpful reviewers. Lastly, this work was supported by the research project 'Fragile Cities,' Academy of Finland (grant 1295044).

\section{Conflict of Interests}

The author declares no conflict of interests.

\section{References}

Alcaldía Mayor de Bogotá. (2011). Decreto 543 de 2011 por el cual se adopta la Política Pública para los Pueblos Indígenas en Bogotá, DC [Decree 543/2011: Public policy for indigenous peoples in Bogota, DC]. Bogotá: Alcaldía Mayor de Bogotá.

Alfred, T., \& Corntassel, J. (2005). Being Indigenous: Resurgences against contemporary colonialism. Government \& Opposition, 40(4), 597-614.

Bhandar, B. (2018). Colonial lives of property: Law, land, and racial regimes of ownership. Durham, NC: Duke University Press.

Blomley, N. (2004). Unsettling the city: Urban land and the politics of property. Abingdon: Routledge.

Bocarejo, D. (2011). Emancipation or enclosement? The spatialization of difference and urban ethnic contestation in Colombia. Antipode, 44(3), 663-683.

Brahinsky, R., Sasser, J., \& MinkoffZern, L. (2014). Race, space, and nature: An introduction and critique. Antipode, 46(5), 1135-1152.

Bryan, J. (2012). Rethinking territory: Social justice and neoliberalism in Latin America's territorial turn. Geography Compass, 6(4), 215-226.

Butler, J. (2015). Notes towards a performative theory of assembly. Cambridge, MA: Harvard University Press.

Cabildo Indígena Muisca de Suba. (1999). Los Muiscas un pueblo en reconstrucción. Bogotá: MJ Editores.

Canessa, A. (2005). Natives making nation: Gender, indigeneity, and the state in the Andes. Tucson, AZ: The University of Arizona Press. 
Canessa, A. (2012). Intimate indigeneities: Race, sex, and history in the small spaces of Andean life. Durham, NC: Duke University Press.

Carillo, M. (1997). Los caminos del agua: Según la tradición oral de los raizales de la Sabana de Bogotá [The paths of water: According to the oral tradition of the raizal people of the Sabana de Bogotá] (Doctoral dissertation). National University of Colombia, Bogotá, Colombia.

Casey, E. S. (2009). Getting back into place: Toward a renewed understanding of the place world. Indianapolis. IN: Indiana University Press.

Corntassel, J. (2018). Everyday acts of resurgence: People, places, practices. Olympia, WA: Daykeeper Press.

Coulthard, G. S. (2014). Red skin, white masks: Rejecting the colonial politics of recognition. Minneapolis, MN: University of Minnesota Press.

De la Cadena, M. (2015). Earth beings: Ecologies of practice across Andean worlds. Durham, NC: Duke University Press.

De la Cadena, M., \& Starn, O. (2007). Indigenous experience today. Oxford: Berg Publishers.

Ellison, S. (2018). Indigeneity in anthropology. In $\mathrm{H}$. Callan (Ed.), The international encyclopedia of anthropology (Vol. 12, pp. 1-12). Hoboken, NJ: Wiley.

Escobar, A. (2008). Territories of difference: Place, movements, life, redes. Durham, NC: Duke University Press.

Heynen, N. (2016). Urban political ecology II. Progress in Human Geography, 40(6), 839-845.

Hill, J. (1996). History, power, and identity: Ethnogenesis in the Americas, 1492-1992. lowa City, IA: University of lowa Press.

Hobsbawm, E., \& Ranger, T. (1983). The invention of tradition. Cambridge: Cambridge University Press.

Jacobs, J. (1996). Edge of empire: Postcolonialism and the city. London: Routledge.

Jenkins, W. (2017). Sustainability. In W. Bauman, R. Bohannon, \& K. O'Brien (Eds.), Grounding religion: $A$ fieldguide to the study of religion and ecology ( $\mathrm{pp}$. 235-250). Abingdon: Routledge.

Kuper, A. (2003). The return of the native. Current Anthropology, 44(3), 389-402.

Langebaek, C. H. (2005). Resistencia indígena y transformaciones ideológicas entre los muiscas de los siglos XVI y XVII [Indigenous resistance and ideological transformation among the Muiscas during the XVI and XVII centuries]. In A. M. G. Londoño (Ed.), Muiscas: Representaciones, cartografías y etnopolíticas de la memoria [Muiscas: Representations, cartographies and the ethnopolitics of memory] (pp. 24-53). Bogotá: Pontificia Universidad Javeriana, Instituto Pensar.

Lefebvre, H. (1991). The production of space. Oxford: Blackwell.

López, M. R. (2005). Los resguardos muiscas y raizales de la sabana de Bogotá: Espacios sociales de construcción de la memoria [The Muisca resguardos and raizal peoples from the Bogota savannah]. In A. M. G. Londoño (Ed.), Muiscas: Representaciones, cartografías y etnopolíticas de la memoria [Muiscas: Representations, cartographies and the ethnopolitics of memory] (pp. 332-347). Bogotá: Pontificia Universidad Javeriana.

López Sandoval, M. F., Robertsdotter, A., \& Paredes, M. (2017). Space, power, and locality: The contemporary use of territorio in Latin American geography. Journal of Latin American Geography, 16(1), 43-67.

Maddison, S. (2013). Indigenous identity, 'authenticity' and the structural violence of settler colonialism. Identities, 20(3), 288-303.

Maldonado-Torres, N. (2007). On the coloniality of being: Contributions to the development of a concept. Cultural Studies, 21(2/3), 240-270.

Malm, A. (2018). The progress of this storm: On society and nature in a warming world. London: Verso.

Manzini, E. (2015). Design, when everybody designs: An introduction to design for social innovation. Cambridge, MA: The MIT Press.

Marcuse, H. (2018). Counterrevolution and revolt. Boston, MA: Beacon Press.

Mignolo, W. D. (2000). Local histories/global design: Coloniality, subaltern knowledges, and border thinking. Princeton, NJ: Princeton University Press.

Ng'weno, B. (2007). Can ethnicity replace race? AfroColombians, indigeneity and the Colombian multicultural state. Journal of Latin American and Caribbean Anthropology, 12(2), 414-40.

Pallares, A. (2002). From peasant struggles to Indian resistance: The Ecuadorian Andes in the late twentieth century. Norman, OK: University of Oklahoma Press.

Povinelli, E. (2002). The cunning of recognition: Indigenous alterities and making of Australian multiculturalism. Durham, NC: Duke University Press.

Povinelli, E. (2011). Economies of abandonment: Social belonging and endurance in late liberalism. Durham, NC: Duke University Press.

Quijano, A. (1997). La colonialidad del poder, cultura y conocimiento en América Latina [Coloniality of power, culture, and knowledge in Latin America]. Anuario Mariateguiano, 9(9), 113-121.

Restrepo, L. (2005). Reflexiones sobre los estudios muiscas y las etnopoliticas de la memoria [Reflections on Muisca studies and the ethnopolitcs of memory]. In A. M. Gómez (Ed.), Muiscas: Representaciones, cartografías y etnopoliticas de la memoria [Muiscas: Representations, cartographies and the ethnopolitics of memory] (pp. 316-330). Bogotá: Editorial Pontificia Universidad Javeriana.

Routledge, P. (2017). Space invaders: Radical geographies of protest. London: Pluto Press.

Sánchez-Castañeda, P. (2018). Mending identity: The revitalization process of the Muisca of Suba (Master's Thesis). Florida International University, Miami, FL.

Shulist, S. (2016). Indigenous names, revitalization politics, and regimes of recognition in the North- 
west Amazon. The Journal of Latin American and Caribbean Anthropology, 21(2), 336-354.

Ulloa, A. (2012). Los territorios indígenas en Colombia: De escenarios de apropiación transnacional a territorialidades alternativas [Indigenous territories in Colombia: From scenarios of transnational appropriation to alternative territorialities]. Scripta Nova: Revista Electrónica de Geografía y Ciencias Sociales, 16(65).

Vega, R. A. (2017). Commodifying indigeneity: How the humanization of birth reinforces racialized inequality in Mexico. Medical Anthropology Quarterly, 31(4), 499-518.

Weaver, H. N. (2001). Indigenous identity: What is it, and who really has it? American Indian Quarterly, 25(2), 240-255.

Wideman, T. J., \& Lombardo, N. (2019). Geographies of land use: Planning, property, and law. Geography Compass, 13(12), 1-14.

Zambrano, M. (2003). Contratiempos de la memoria social: Reflexiones sobre la presencia indigena en Santa $\mathrm{Fe}$ y Bogota [Setbacks of social memory: Reflections on the indigenous presence in Santa Fe and Bogota]. Paper presented at Reunion anual del Proyecto Identidades y movilidades CIESAS-ICANH, Mexico City, Mexico.

Zieleniec, A. (2018). Lefebvre's politics of space: Planning the urban as oeuvre. Urban Planning, 3(3), 5-15.

\section{About the Author}

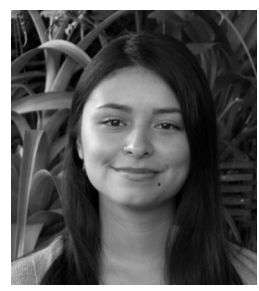

Paola Andrea Sánchez-Castañeda is a PhD Student of Anthropology in the Department of Global and Sociocultural Studies at Florida International University in Miami, Florida, USA. Her research works across the fields of urban political ecology, Indigenous studies, and decolonial methodologies, particularly Participatory Action Research. Currently, Andrea's work focuses on the spatialization of Indigenous identity, performance, and everyday acts of resistance in urban indigenous communities in Colombia. 